\title{
ANALISIS PERMINTAAN TAKSI KONVENSIONAL DI TENGAH BEROPERASINYA TAKSI ONLINE DI KOTA MAKASSAR
}

\author{
Muhammad Jibril Tajibu \\ Bachtiar Rezkiawan Narwis \\ Abdul Rahman Razak \\ Kasnaeny Karim
}

Fakultas Ekonomi dan Bisnis Universitas Hasanuddin Makassar

e-mail: mjtajibu@gmail.com

\begin{abstract}
The purpose of this study was to analyze the demand for conventional taxis in the middle of online taxi operations, namely (1) The effect of income on conventional taxi demand, (2) The effect of conventional taxi rates on conventional taxi demand, (3) The effect of online taxi fares on conventional taxi demand (4) The effect of online taxi waiting times on conventional taxi demand (5) The effect of consumer needs on conventional taxi demand. The study was conducted on 135 respondents. To answer the research problem, the analysis was carried out using multiple linear regression. The results of the analysis show that (1). Income has a significant positive effect on conventional taxi demand (2). Conventional taxi fares have a significant negative effect on conventional taxi demand. (3) online taxi rates have a significant positive effect on conventional taxi demand, (4). Online taxi waiting times have a significant negative effect on conventional taxi demand and (5). This type of need has a significant positive effect on the demand for conventional taxis
\end{abstract}

Keywords: demand of conventional taxi, online taxi, income, and taxi fares

\section{PENDAHULUAN}

Transportasi memiliki peran strategis dalam menggerakkan roda perekonomian nasional di lain pihak, bidang transportasi ini juga merupakan lahan bisnis sebagaiman sektor ekonomi lainnya. Bidang angkutan ini mencakup angkutan laut, angkutan jalan raya, angkutan sungai, angkutan udara, angkutan rel, dan jasa penunjang angkutan. Perkembangan bidang angkutan ini dapat dilihat dari kontribusi masing-masing jenis angkutan terhadap Produk Domestik Bruto (PDB). Jika kita melihat perkembangan sarana transportasi di Indonesia sungguh sangat mengalami kemajuan yang sangat drastis seperti kita dapat melihat bahwa saat ini untuk menjangkau atau memesan sarana angkutan saja kita dapat memesan hanya dengan menggunakan aplikasi pada smartphone.

Pengangkutan atau transportasi secara umum mempunyai pengaruh besar terhadap perorangan, masyarakat, pembangunan ekonomi, dan sosial politik suatu negara. transportasi merupakan sarana dan prasaran bagi pembangunan ekonomi negara yang bisa mendorong laju pertumbuhan ekonomi (Rate of Growth). Dalam era globalisasi sekarang ini, sektor transportasi merupakan sarana yang sangat penting dan strategis dalam memperlancar roda perekonomian serta mempengaruhi semua aspek kehidupan. Pentingnya transportasi tersebut tercermin pada semakin meningkatnya kebutuhan akan jasa angkutan, mobilitas orang serta barang dari dan ke seluruh pelosok tanah air, bahkan dari dan ke luar negeri (Fajariah, 2017).

Manusia pada zaman ini, sangat membutuhkan transportasi yang dapat mempermudah dalammelakukan berbagai kegiatan, termasuk mendukung perpindah mereka dari satu tempat ke tempat lain secara mudah. Dalam hal ini,maka teknologi mempunyai peranan yang sangat penting untuk menunjang kemudahan tersebut. Sudah banyak teknologi yang diciptakan oleh manusia untuk mewujudkan keinginan manusia itu sendiri. Upaya yang dilakukan ini, agar kita tidak perlu 
lagi repot-repot untuk melakukan aktifitas yang melelahkan.

Kemajuan teknologi tidak saja memudahkan industri-industri manufaktur, namun ada industri jasa transportasi juga kini sangat berkembang. Di era perkembangan ilmu pengetahuan saat ini teknologi mengalami perkembangan yang sangat pesat, bahkan perkembangan teknologi yang pesat menyentuh semua aspek kehidupan manusia. Secara langsung pula teknologi juga akan berpegaruh terhadap pola perilaku manusia dalam ekonomi. Dalam hal ini ekonomi telah menyentuh sektor transportasi, perkembangan teknologi pada sektor transportasi tentu dapat kita lihat pada bagaimana akses untuk mendapatkan jasa transportasi dapat dijangkau hanya dengan sentuhan pada smartphone yang secara umum telah dimiliki oleh setiap orang.

Pergerakan dan perjalanan adalah hasil dari kebutuhan manusia untuk bergerak dari satu tempat ke tempat lain untuk berbagai aktivitasnya, sehingga menghasilkan profil pergerakan yang berbeda bagi setiap individunya dan berpotensi sebagai penyebab timbulnya berbagai permasalahan kota, diantaranya adalah permasalahan mengenai jasa transportasi. Tingginya laju urbanisasi di kota - kota besar juga akan berimplikasi pada peningkatan kebutuhan dalam melakukan mobilitas atau pergerakan. Kelancaran pergerakan (aksebilitas) akan melahirkan suatu kelancaran bagi pertukaran kebutuhan penduduk dan akhirnya pada percepatan ekonomi terhadap beberapa pilihan moda transportasi pada pengguna sarana angkutan umum penumpang.

Makassar adalah salah satu kota terbesar di Indonesia yang memiliki lokasi yang strategis dilihat dari segi komunikasi, maupun perekonomian. Sebagai kota terbesar secara otomatis akan membuat kota Makassar menjadi pusat penunjang bagi penduduknya. Luas wilayah kota Makassar seluruhnya berjumlah kurang lebih $175,77 \mathrm{Km} 2$ daratan dan termasuk 11 pulau di selat Makassar ditambah luas wilayah perairan kurang lebih $100 \mathrm{Km}^{2}$. dengan luas tersebut secara otomatis harus ditunjang oleh sarana transportasi yang memadai untuk menunjang mobilitas penduduk, baik untuk melakukan ekonomi maupun aktivitas kehidupan sehari-hari (makassarkota.go.id, 2016).

Jumlah penduduk Kota Makassar terus mengalami peningkatan setiap tahun. Hal tersebut terlihat dari data yang dilansir Dinas
Kependudukan dan Pencatatan Sipil. Tahun 2015 jumlah penduduk Kota Makassar berada diangka 1.653.386 jiwa. Angka tersebut mengalami penambahan sebesar 5.117 jiwa ditahun 2016 menjadi 1.658.503 jiwa. Sedang tahun 2017 angka ini kembali mengalami meningkatan yang cukup signifikan sebesar 111.417 jiwa. Sehingga, jumlah penduduk di Kota Daeng hingga Maret 2017 mencapai 1.769.920 jiwa. (berita-sulsel.com,2017).

Untuk menunjang mobilitas keseharian penduduk yang banyak tersebut maka akan mengakibatkan semakin banyaknya jasa transportasi yang harus di sediakan baik yang di sediakan oleh pemerintah maupun perseorangan maupun swasta. Jasa transportasi yang disediakan oleh pemerintah belum sepenuhnya menyentuh semua bagian dari kota Makassar, misalnya sampai pada komplek atau gang dalam kota. Maka bermunculanlah jasa transportasi yang dapat menjangkau misalnya jasa becak, becak motor, dan ojek.

Ojek, menjadi salah satu yang terpopuler diantara sarana transportasi lainnya. Menggunakan motor sebagai alat transportasinya, membuat berkendara menggunakan ojek lebih cepat dibandingkan dengan angkot, bus, maupun taksi.

Dengan kemacetan yang kini sering sekali terjadi di Kota Makassar, membuat warga Makassar lebih memilih ojek sebagai alat transportasi agar dapat lebih cepat tiba ditempat tujuan. Warga Makassar pun lebih mudah mengakses ojek tersebut karena biasanya para tukang ojek memiliki pangkalan didaerahnya masing-masing, sehingga warga tidak perlu repotrepot menunggu transportasi mereka. untuk menghampiri mereka.

Dengan kemajuan teknologi informasi yang ada, muncul transportasi umum yang dapat diakses menggunakan gadget. Berawal dari Jakarta sebagai pencetus ojek online di Indonesia, kini ojek online juga telah marak dikalangan warga Kota Makassar. Keinginan masyarakat untuk beralih dari angkutan konvensional ke on line dipengaruhi oleh faktor kecanggihan alat komunikasi (teknologi) dan dan didukung oleh keinginan masyarakat yang senantiasa menghendaki kemudahan, apalagi dengan kondisi lalu lintas di kota Makassar yang makin padat. Perilaku masyarakat dalam menyikapi perubahan akan menerima jika perubahan itu memberikan keuntungan, seperti kenyamanan, kecepatan, menguntungkan, tidak merusak prestise, meningkatkan taraf hidup, tidak bertentangan dengan nilai yang dianut. 
Setiap pengguna transportasi ojek kini dapat menggunakan handphone dengan aplikasi khusus untuk dapat mengakses ojek online. Bukan hanya ojek online yang dapat ditemukan sebagai alat transportasi, kini tersedia pula taksi online.

Keberadaan taksi online merupakan alternatif bagi masyarakat yang menginginkan bukan hanya kecepatan dalam perjalanan, tetapi juga kenyamanan. Meski pada awalnya mendapatkan penolakan dari pengemudi taksi konvensional, namun jumlah taksi online kian bertambah seiring dengan kebutuhan masyarakat kota Makassar dalam hal transportasi.

Survey yang dilakukan oleh Yayasan Lembaga Konsumen Indonesi (YKLI), pada bulan April 2017 terkait dengan keberadaan angkutan umum berbasis online yang tidak tercakup dalam trayek, mengungkap alasan yang dikemukakan oleh masyarakat yang memilih atau menggunakan transportasi online, yakni: murah $(84,1 \%)$, cepat $(81,9 \%)$, nyaman $(78,8 \%)$, dan aman $(61,4 \%)$ (Anwar, 2017).

Ini menunjukkan bahwa kemurahan tarif layanan menduduki rangking pertama pilihan responden. Adapun moda transportasi yang dipilih konsumen adalah transportasi online jenis mobil dan motor $(55 \%)$; mobil saja (24\%), dan motor saja $(21 \%)$. Selain itu, Go-Jek menduduki rating tertinggi pilihan konsumen $(72,6 \%)$; diikuti oleh Grab (66,9\%); kemudian Uber (51\%), dan terakhir My BlueBird (4,4\%), (Tribunnews 2017). Menariknya, meskipun Uber tidak terlalu populer sebagai layanan transportasi online, ia dipilih oleh $51 \%$ responden, sementara My Bluebird dipilih hanya oleh 4,4\% responden. Ini kemungkinan karena imej Bluebird yang meskipun memiliki 'nama baik' dalam layanan transportasi, namun imej 'mahal' juga melekat padanya, sehingga kurang diminati oleh pengguna layanan transportasi (Anwar, 2017).

Sejak beroperasinya taksi online yang berbasis aplikasi di Kota Makassar pada tahun 2016, maka jenis taksi terbagi menjadi 2 jenis, yakni taksi konvensional dan taksi online (Grab/GoCar/Uber). Kehadiran taksi online memiliki dinamika tersendiri terhadap pasar taksi konvensial khususnya dari sisi demand.

Taksi konvensional yang beroperasi di Kota Makassar selama 5 bulan terakhir secara umum mengalami penurunan seperti yang ditunjukkan pada Tabel 1. Posisi maret 2017, permintaan taksi konvensional berjumlah 21.547 unit. Permintaan taksi terus menurun hingga bulan juni 2017 yang secara berturut-turut penurunan permintaan tersebut sebesar $0,44 \%$ di bulan april, $0,03 \%$ di bulan mei dan $2,66 \%$ di bulan juni. Penurunan terbesar berada pada periode Juni di mana permintaan taksi menurun hingga $2,66 \%$ dan mencapai angka 20.886 unit permintaan taksi konvensional. Permintaan taksi baru kembali mengalami peningkatan pada bulan juli 2017 sebanyak 21.254 unit atau meningkat sebesar $1,76 \%$ dari periode sebelumnya. Secara umum, selama 5 bulan terakhir atau periode Maret hingga Juli terlihat persentase dari $-0,44 \%$ hingga $1,76 \%$ pertumbuhan permintaan taksi konvensional di Kota Makassar menurun sebesar $1,37 \%$.

Tabel 1

Jumlah Permintaan Taksi Konvensional di Kota Makassar

\begin{tabular}{cccc} 
No & Tahun & Jumlah & Persentasi (\%) \\
\hline 1 & Maret 2017 & 21.547 & - \\
\hline 2 & April 2017 & 21.453 & $(0,44)$ \\
\hline 3 & Mei 2017 & 21.447 & $(0,03)$ \\
\hline 4 & Juni 2017 & 20.886 & $(2,66)$ \\
\hline 5 & Juli 2017 & 21.254 & $1,76 \%$ \\
\hline
\end{tabular}

Sumber: Asosiasi Pengusaha Taksi Sulawesi Selatan (diolah).

Sebagaimana halnya taksi konvensional, taksi online hampir memiliki seluruh atribut pelayanan yang bisa diberikan oleh taksi konvensional. Perubahan model transportasi dari konvensional ke transportasi berbasis aplikasi sangat diminati masyarakat dan ini merupakan suatu bentuk perubahan sosial masyarakat yang menghendaki kemudahan dalam penggunaan moda transportasi. Perubahan-perubahan yang terjadi pada masyarakat merupakan gejala yang normal. 
Pengaruhnya bisa menjalar dengan cepat ke bagian-bagian dunia lain berkat adanya komunikasi modern (Soekanto 2009:259).

Berdasarkan adanya kesamaan atribut pelayanan tersebut maka jasa taksi konvensional dan jasa taksi online merupakan 2 komoditas yang memiliki keterkaitan erat dari sisi permintaan.

Frekuensi permintaan taksi, baik taksi konvensional maupun taksi online sangat dipengaruhi oleh harga atau tarifnya. Harga tersebut dapat diukur melalui biaya-biaya yang dikeluarkan oleh pengguna seperti biaya langsung (tarif), waktu dalam menunggu taksi dan waktu perjalanan (Horn, 2002:174). Keterkaitan harga dan permintaan antara 2 komoditas transportasi ditegaskan oleh Waters \& Yong (1990:13) yang melakukan penelitian tentang elastisitas harga pada moda transportasi dan menyimpulkan bahwa elastisitas harga dan elastisitas harga silang pada "intermodal competition" sangat elastis. Artinya jika terjadi sedikit perubahan harga baik pada moda transportasi tertentu maupun moda transportasi kompetitornya akan mengubah demand pada moda transportasi tersebut.

Derived demand yang dijelaskan oleh Todaro \& Smith (2012:377) merupakan permintaan terhadap barang dan jasa yang timbul secara langsung dari permintaan atas barang dan jasa lainnya. Sedangkan dari sudut pandang yang berbeda, Karlan \& Morduch (2014:366) menjelaskan derived demand sebagai permintaan atas barang atau jasa yang menjadi faktor produksi atas barang dan jasa lain. Meskipun menjelaskan dari sudut pandang yang berbeda, namun baik Todaro \& Smith maupun Karlan \& Morduch mendefinisikan derived demand sebagai permintaan barang dan jasa yang erat kaitannya dengan permintaan atas barang dan jasa lainnya.

Perilaku konsumen yang membentuk demand dijelaskan oleh Henderson \& Quandt (1985:5), Varian (2010:18), Hall \& Lieberman (2010:153), Case (2012:122), Slavin (2014:132), Parkin (2014:122), Mankiw (2015:39) dan Karlan \& Morduch (2017:190) memberikan catatan teoritis yang saling melengkapi satu dengan yang lain. Namun secara umum semua ahli tersebut memberikan definisi yang sama, yakni adanya hubungan yang tidak searah antara harga dan jumlah permintaan atas barang dan jasa. Semakin tinggi harga suatu barang atau jasa maka semakin rendah jumlah barang yang diminta, demikian juga sebaliknya, semakin rendah harga suatu barang atau jasa maka semakin banyak barang atau jasa yang diminta.
Hukum permintaan ini dapat digunakan untuk menjelaskan mengapa konsumen maupun rumah tangga secara rasional akan meningkatkan frekuensi penggunaan jasa transportasi saat harga atau biaya jasa transportasi itu lebih murah dibanding saat harga atau biaya jasa transportasi tersebut tinggi.

Menurut Sukirno,1994 dalam Fajariah, 2017, terdapat beberapa faktor yang mempengaruhi permintaan tersebut dijabarkan sebagai berikut :

1. Harga barang itu sendiri

2. Harga barang lain

3. Pendapatan

4. Selera

5. Faktor-faktor lain

Permintaan jasa transportasi tidak berdiri sendiri, melainkan tersembunyi dibalik kepentingan yang lain. Pada dasarnya permintaan angkutan diakibatkan oleh hal-hal berikut, (Nasution, 2004 dalam Fajariah, 2017) :

1. Kebutuhan manusia untuk bepergian dari ke lokasi lain dengan tujuan mengambil bagian didalam suatu kegiatan, misalnya bekerja, berbelanja, ke sekolah, dan lain-lain.

2. Kebutuhan angkutan barang untuk dapat digunakan atau dikonsumsi dilokasi lain.

Selanjutnya menurut Nasution 2004, Faktorfaktor yang mempengaruhi permintaan jasa angkutan adalah sebagai berikut:

1. Harga jasa angkutan

2. Tingkat pendapatan

3. Citra atau image terhadap perusahaan atau moda transportasi tertentu

Permintaan atas barang atau jasa tidak hanya ditentukan oleh harga atas barang tersebut, tetapi ada juga faktor-faktor lain. Case (2012:122) maupun Parkin (2014:122) menjelaskan beberapa faktor yang mempengaruhi jumlah barang yang diminta oleh rumah tangga, yaitu harga barang atau jasa itu sendiri, harga dari barang yang berkaitan erat dengan barang atau jasa yang diminta (subtitusi maupun komplementer), pendapatan rumah tangga, akumulasi kekayaan rumah tangga, selera, kenyamanan, dan juga ekspektasi pendapatan di masa yang akan datang.

Pengaruh pendapatan terhadap permintaan moda transportasi telah dibuktikan oleh McFadden (1974:319), Bento et al (2003:16) dan Souche (2011:132). Meskipun pada lokasi dan waktu yang berbeda, mereka menemukan bahwa adanya 
pengaruh positif variabel pendapatan terhadap permintaan moda transportasi. Pada moda transportasi yang lebih spesifik yaitu taksi ditemukan oleh Souche (2011:132) dan berkesimpulan bahwa adanya pengaruh positif variabel pendapatan terhadap permintaan taksi.

Biaya perjalanan atau tarif moda transportasi juga merupakan salah satu faktor penting yang mempengaruhi permintaan moda transportasi itu sendiri, hal tersebut dibuktikan oleh McFadden (1974:319), Bento et al (2003:16), Souche (2011:132). Mereka bermuara pada kesimpulan yang sama, yakni biaya perjalanan atau tarif moda transportasi berpengaruh negatif terhadap banyaknya permintaan moda transportasi itu sendiri. Pada kasus yang lebih spesifik yakni taksi ditemukan oleh Schaller (2005:74), Yang et al (2010:347), dan Wang \& Huang (2013:124). McFadden (1974:319) menemukan adanya efek substitusi yang terjadi pada multimoda karena faktor harga atau biaya yang dikeluarkan oleh masyarakat dalam memilih moda transportasi yang akan digunakannya.

Waktu tunggu taksi juga ikut mempengaruhi banyaknya permintaan taksi. Berkurangnya waktu tunggu taksi meningkatkan banyaknya jumlah permintaan taksi. Pengaruh negatif waktu tunggu tersebut ditemukan oleh Yang et al (2010:347) dan Rayle, et al (2014:11). Pada kasus hasil penelitian yang lebih umum yakni pada moda transportasi umum sebelumnya telah dilakukan oleh McFadden (1974:319), Mishalani, et al (2006:103), Watkins et al (2011:12) dan Cats et al (2013:2).

Rayle, et al (2014:11) melakukan survey pada pengguna taksi yang memiliki kendaraan pribadi di San Francisco. Salah satu variabel yang menjadi observasinya yaitu tujuan perjalanannya menggunakan taksi (trip purpose). Rayle menemukan bahwa $67 \%$ respondennya menggunakan taksi untuk tujuan aktivitas sosial seperti menuju bar, restoran, konser dan mengunjungi keluarga dan teman. Hanya $16 \%$ yang menggunakan taksi untuk aktivitas bekerja sehari-hari, $4 \%$ menuju atau dari bandara dan $10 \%$ untuk tujuan ke dokter atau janji lainnya.

Sementara itu, penelitian dari Prabawati (2017) menyatakan bahwa keputusan menggunakan taksi konvensional dengan obyek penelitian pada Taksi Blue Bird, memperlihatakan bahwa perusahaan tersebut menerapkan strategi bauran pemasaran yang teridiri dari Product, Price, Place, Promotion, People, Process, dan Physical Evidence.
Produk (Product) merupakan segala sesuatu yang menjadi kebutuhan dan keinginan konsumen. Produk dapat berbentuk barang dan jasa dan kombinasi antara barang dan jasa. Taksi merupakan produk yang merupakan jasa namun berwujud kendaraan, sehingga merupakan paduan antara barang dan jasa. Sebagai produk yang tidak berwujud maka taksi lebih menonjolkan layanan. Manfaat dari produk ini akan diangga berkualitas jika mampu memberikan kepuasan kepada pengguna taksi.

Masyarakat memilih sebuah produk karena adanya nilai yang diharapkan diperoleh dari produk tersebut. Konsumen akan rela membayar lebih jika diyakini produk tersebut memberi manfaat bagi konsumen. Manakala harapan konsumen sesuai dengan kenyataan yang didapatkan setelah mengkonsumsi produk tersebut sesuai, maka konsumen akan puas, namun manakala hal tersebut tidak sesuai maka yang terjadi adalah ketidakpuasan.

Harga (Price), merupakan biaya yang dikenakan oleh perusahaan atas layanan sebuah produk. Harga adalah jumlah uang (ditambah beberapa barang kalau mungkin) yang dibutuhkan untuk mendapatkan sejumlah kombinasi dari barang beserta kelengkapannya Harga pada industri taksi yaitu tarif yang dikenakan pada pengguna. Penentuan tarif ini akan dapat berpengaruh terhadap permintaan taksi konvensional. Konsumen pada dasarnya bersedia membeli dengan harga yang tinggi dibanding harga produk sejenis, manakala diimbangi dengan kualitas yang tinggi. Hal ini disebabkan masyarakat menganggap harga yang mahal menandakan kualitas yang bagus.

Saluran distribusi (Place), merupakan kegiatan pendistribusian produk kepada masyarakat. Saluran distribusi bertugas memindahkan barang dari produsen ke konsumen. Berarti saluran distribusi mengatasi kesenjangan waktu, tempat dan kepemilikan yang memisahkan barang dan jasa dari orang-orang yang membutuhkan atau menginginkannya.

Perusahaan taksi memperhatikan pendistribusian melalaui kecepatan dan ketepatan berada pada tempat yang diinginkan oleh pelanggan. Masyarakat menginginkan tersedianya taksi konvensional pada setiap tempat yang mereka inginkan, sehingga ketika masyarakat menginginkan, maka akan ada pada waktu yang tepat.

Promosi (Promotion), adalah kegiatan pemasaran yang berbentuk penyampaian pesan 
kepada konsumen mengenai keberadaan produk. Komunikasi yang dibentuk oleh perusahaan akan membuat konsumen menyadari akan produk, mengetahui akan manfaat dan kelebihan produk perusahaan dibanding produk pesaing. Untuk bisa berkomunikasi secara efektif biasanya perusahaan menyewa biro iklan untuk merancang iklannya, membayar biro hubungan masyarakat atau mendidik karyawannya supaya bersikap ramah dan mampu memberi informasi yg jelas.

Terdapat empat bauran promosi, yaitu:

a. Iklan, Periklanan merupakan bentuk-bentuk komunikasi non personal yang dilakukan lewat media, atau iklan merupakan berita tentang barang dan jasa. Manfaat iklan yaitu. Pembentukan citra organisasi dlm jangka panjang (iklan institusional), pemantapan merk dagang (iklan produk), penyebaran informasi tentang penjualan, jasa dan peristiwa (iklan klasifikasi), pengumuman penjualan khusus (iklan penjualan, anjuran untuk melakukan sesuatu (iklan anjuran).

b. Promosi Penjualan. Merupakan bentuk promosi yang menekankan pada ajakan agar masyarakat mau menggunakan produk itu segera (sekarang). Agar konsumen mau membeli sekarang maka dilakukan beberapa program yaitu, pemberian diskon, hadiah-hadiah, sampel gratis, dan kupon-kupon hadiah.

c. Publisitas. Merupakan bentuk pomosi yang lebih menekankan pada penciptaan citra perusahaan. Tujuan publisitas yaitu menciptakan good relation pada publik dan mencegah berita tak baik dari masyarakat.

d. Personal Selling. Yaitu bentuk promosi dimana karyawan berusaha untuk mempengaruhi masyarakat untuk membeli, contoh salesman

Orang (People), Menurut Elliott,et al (2012:23) "People refers to any person coming into contact with customer who can affect value for customers"

Penerapan strategi pemasaran bauran orang (driver) yang telah dilakukan oleh jasa transportasi taksi konvensional Blue Bird dimana pihak perusahaan memberikan pembekalan dan pengarahan kepada driver mereka sebelum memberikan pelayanan kepada konsumen, perusahaan memiliki standar tersendiri untuk para driver saat mengemudi dan melayani konsumen.

Layanan karyawan taksi konvensional akan sangat membantu dalam membuat konsumen tetap memilih untuk menggunakan produk. Kecepatan layanan, ketanggapan karyawan terhadap keinginan dan masalah konsumen akan membuat konsumen merasa kebutuhannya akan layanan yang berkualitas terpenuhi. Demikian halnya pada perusahaan taksi, dimana layanan karyawan diukur melalui kecepatan karyawan menanggapi order dari pengguna taksi, dan ketepatan dalam memberi informasi ke driver taksi. Hal ini juga terkait dengan layanan driver terhadap pengguna taksi. Driver harus memberi perasaan aman dan nyaman selama perjalanan, dan mampu menumbuhkan rasa percaya pengguna terhadap driver.

Proses (Process), merupakan bauran pemasaran yang juga dilakukan oleh perusahaan transport taksi konvensional Blue Bird yaitu flowcharting dan blueprinting. Dimana flowcharting merupakan langkah demi langkah penyampaian jasa kepada konsumen, perusahaan taksi Blue Bird sendiri dalam menyampaikan jasa ke konsumen, dimana konsumen menelpon atau melalui aplikasi online untuk melakukan order, kemudian pihak operator menyampaikan order ke driver. Driver menuju lokasi konsumen maksimal 10 menit jadi konsumen tidak perlu menunggu lama dan kemudian taksi mengantarkan kossumen sampai ketujuan dengan tepat waktu Sedangkan blueprinting bagaimana jasa yang disampaikan kepada konsumen dibagi menjadi 2 yaitu jasa yang bisa dilihat oleh konsumen dan bagian pendukung jasa yang tidak dapat dilihat oleh konsumen. Dimana perusahaan Blue Bird dalam proses penyampaian jasa kepada konsumen memberikan rasa nyaman dan memberikan kepuasan kepada konsumen dengan proses yang cepat dan tepat sampai tujuan (Prabawati, 2017)

Dengan demikian ingin diketahui; (1) Pengaruh pendapatan terhadap permintaan taksi konvensional, (2) Pengaruh tarif taksi konvensional terhadap permintaan taksi konvensional, (3) Pengaruh tarif taksi online terhadap permintaan taksi konvensional (4) Pengaruh waktu tunggu taksi online terhadap permintaan taksi konvensional (5) Pengaruh jenis kebutuhan terhadap permintaan taksi

\section{METODE PENELITIAN Jenis Penelitian}

Penelitian ini merupakan penelitian eksplanatori dengan pendekatan kuantitatif dengan cara menguji hipotesis yang diajukan untuk menjelaskan pengaruh pendapatan, tarif taksi konvensional, tarif taksi online, waktu tunggu dan jenis kebutuhan taksi konvensional terhadap 
permintaan taksi konvensional di tengah beroperasinya taksi online di Kota Makassar.

\section{Populasi dan Sampel}

Populasi dalam penelitian ini adalah seluruh pengguna taksi konvensional yang ada di Kota Makassar. Data pengguna taksi konvensional di Kota Makassar pada tahun 2017 yaitu sebanyak 13.235 pelanggan baik aktif maupun tidak aktif. Oleh karena adanya keterbatasan sumber daya maka penelitian ini akan menarik sampel sebanyak 135 melalui metode acak sederhana (simple random sampling), di mana seluruh populasi memiliki kesempatan yang sama untuk terpilih sebagai sampel. Menurut Fraenkel et al (2012), "There are a few guidelines that we would suggest with regard to the minimum number of subjects needed. For descriptive studies, we think a sample with a minimum number of 100 is essential. For correlational studies, a sample of at least 50 is deemed necessary to establish the existence of a relationship". Dengan kata lain untuk penelitian deskriptif jumlah sampel sebanyak 100 sudah mencukupi. Dengan demikian jumlah sampel sebanyak 135 sampel atau sebesar 1 persen dari jumlah populasi (132,35 dibulatkan menjadi 135) dalam penelitian ini sudah cukup mewakili populasi di mana diasumsikan seluruh responden adalah homogen.

\section{Teknik Pengumpulan Data}

Jenis data yang dikumpulkan dalam penelitian ini adalah data primer dan data sekunder. Data primer bersumber dari para responden dan hasil observasi. Sedangkan data sekunder akan dikumpulkan dari berbagai sumber seperti, Dinas Perhubungan Kota Makassar, BPS Kota Makassar dan hasil-hasil penelitian sebelumnya.

\section{Teknik Analisis Data}

Teknik analisis data dalam penelitian ini adalah regresi linear berganda. Model penelitian dapat digambarkan sebagai berikut:

$$
\begin{aligned}
& Y=\beta_{0}+\beta_{1} X_{1}+\beta_{2} X_{2}+\beta_{3} X_{3}+\beta_{4} X_{4}+\beta_{5} X_{5}+\varepsilon \\
& \text { di mana } \\
& \mathrm{Y} \quad=\text { Permintaan taksi konvensional } \\
& \text { (Frekuensi) } \\
& \mathrm{X}_{1} \quad=\text { Pendapatan (Rupiah) } \\
& \mathrm{X}_{2} \quad=\text { Tarif (Rupiah) } \\
& \mathrm{X}_{3} \quad=\text { Tarif taksi online (Rupiah) } \\
& \mathrm{X}_{4} \quad=\text { Waktu tunggu (Menit) } \\
& \mathrm{X}_{5} \quad=\text { Jenis kebutuhan (Dummy }=\text { Rutin }
\end{aligned}
$$

$$
\begin{array}{lll} 
& & \text { dan Non Rutin) } \\
\beta_{0} & = & \text { Intersep } \\
\beta_{1}, \beta_{2}, & = & \text { Koefisien regresi } \\
\beta_{3}, \beta_{4}, & \\
\beta_{5} & \\
\varepsilon & =\text { Variabel gangguan (errors terms) }
\end{array}
$$

Permintaan taksi konvensional diukur dengan satuan frekuensi, yaitu berapa kali seseorang menggunakan taksi konvensional selama 1 bulan terakhir. Sedangkan pendapatan diukur dengan satuan rupiah, besarnya penghasilan bersih yang diterima oleh responden setiap bulan. Tarif taksi konvensional juga diukur dengan satuan rupiah, atau besarnya pembayaran taksi konvensional yang dikeluarkan oleh responden selama 1 bulan terakhir, dibagi dengan frekuensi penggunaan taksi konvensional selama 1 bulan terakhir. Demikian juga dengan tarif taksi online, diukur dengan satuan rupiah, atau besarnya pembayaran taksi online yang dikeluarkan oleh responden selama 1 bulan terakhir, dibagi dengan frekuensi penggunaan taksi online selama 1 bulan terakhir.

Waktu tunggu taksi konvensional diukur dengan satuan menit, yakni lamanya waktu yang dibutuhkan oleh responden dalam menunggu datangnya taksi konvensional setelah melakukan pemesanan taksi konvensional. Sedangkan jenis kebutuhan merupakan variabel dummy (rutin dan non-rutin). Untuk kebutuhan rutin (kantor/ kampus/ sekolah/ pusat perbelanjaan/ kebutuhan rutin lainnya) maka diberi angka "1", sedangkan jika responden menggunakan taksi konvensional untuk kebutuhan non-rutin (bandara/ dokter/ rumah sakit/ liburan/ mendesak/ kebutuhan non-rutin lainnya) maka diberi angka " 0 ".

\section{PEMBAHASAN}

Dari total 135 responden pengguna taksi konvensional di Kota Makassar, terdapat 77 orang (57\%) berjenis kelamin perempuan dan 58 orang $(43 \%)$ berjenis kelamin laki-laki. Sedangkan berdasarkan jenis pekerjaan atau profesi pengguna taksi konvensional di Kota Makassar didominasi oleh Pegawai/Karyawan/Pekerja Sektor Formal dengan jumlah responden sebanyak 71 orang $(52,6 \%)$, Wirausaha/Enterpreneur sebanyak 22 orang (16,3\%), Mahasiswa dan Pelajar sebanyak 11 orang $(8,1 \%)$, Ibu Rumah Tangga sebanyak 11 orang $(8,1 \%)$ dan Lainnya sebanyak 20 orang $(14,8 \%)$.

Taksi konvensional digunakan untuk kebutuhan rutin hanya sebesar $8,9 \%$ atau 12 orang 
dari total 135 pengguna taksi, sedangkan untuk kebutuhan non rutin sebanyak 123 orang atau sebesar 91,1\%. Data tersebut menunjukkan bahwa pasar taksi konvensional lebih banyak pada segmen pengguna dengan kebutuhan non rutin atau kebutuhan mendesak seperti ke bandara, dokter, rumah sakit, liburan dan lain-lain.

Dengan demikian dapat dinyatakan bahwa masyarakat menggunakan taksi konvensional bukan untuk kegiatan-kegiatan rutin dan berulang yang dilakukan setiap hari,namun hanya digunakan untuk kegiatan-kegiatan non rutin yang tidak terjadwal dan mendadak Untuk kegiatan yang mendesak maka taksi merupakan alternatif angkutan yang lebih tepat. Kondisi yang tersebut disebabkan karena konsumen bisa lebih fokus tanpa harus menyetir dalam keadaan tidak terencana. Konsumen lebih butuh taksi jika ke bandara daripada menggunakan kendaraan peribadi.

Nilai R sebesar 0,772 menunjukkan bahwa permintaan taksi konvensional $77,2 \%$ dipengaruhi oleh variabel-variabel bebas yang diobservasi dalam penelitian ini yaitu pendapatan, tarif taksi konvensional, tarif taksi online, waktu tunggu dan jenis pemanfaatan. Sedangkan 22,8\% lainnya dipengaruhi oleh variabel lain di luar model penelitian ini.

Pada tingkat kepercayaan 95\% dan derajat kebebasan sebesar 5 menghasilkan $\mathrm{F}$ hitung sebesar 38,065. Ditemukan bahwa variabel pendapatan, tarif taksi konvensional, tarif taksi online, waktu tunggu, jenis kebutuhan taksi konvensional secara bersama-sama memiliki pengaruh yang signifikan terhadap variabel permintaan taksi konvensional.

Berdasarkan koefisien hasil regresi dan tingkat signifikansi tiap variabel maka diperoleh hasil sebagai berikut:

$$
\begin{gathered}
\hat{Y}=1,195+4,181 E^{007} X_{1}-2,064 E^{005} X_{2}+4,042 E^{005} X_{3}-0,043 X_{4}+3,224 X_{5} \\
(0,069) \quad(0,000) \quad(0,000) \quad(0,000) \quad(0,019) \quad(0,000)
\end{gathered}
$$

Nilai konstanta sebesar 1,195 menunjukkan bahwa jika variabel-variabel bebas yang diobservasi dalam penelitian ini yaitu pendapatan, tarif taksi konvensional, tarif taksi online, waktu tunggu dan jenis pemanfaatan dianggap tetap, maka permintaan taksi konvensional di Kota Makassar sebanyak 1,195 unit.
Penjelasan untuk masing-masing variabel, sebagai berikut:

1. Nilai $\mathrm{t}$ hitung variabel pendapatan (X1) sebesar 7,457, berarti hipotesis "pendapatan berpengaruh signifikan terhadap permintaan taksi konvensional" dapat diterima. Koefisien regresi sebesar 0,0000004181 menunjukkan bahwa arah hubungan pendapatan pengguna taksi konvensional terhadap permintaan taksi konvensional di Kota Makassar adalah positif. Hal ini berarti jika variabel lain dianggap tetap dan pendapatan pengguna taksi konvensional meningkat sebesar 1.000 .000 Rupiah maka akan menambah permintaan taksi konvensional sebanyak 0,418 Unit. Hasil penelitian ini sejalan dengan penelitian yang dilakukan oleh McFadden (1974:319), Bento (2003:9), dan Souche (2011:132).

Pendapatan masyarakat yang meningkat, akan meningkatkan permintaan terhadap taksi konvensional. Maknanya bahwa masyarakat jika mempunyai pendapatan yang lebih, akan memilih menggunakan taksi konvensional dibanding menggunakan angkutan berupa ojek atau angkutan kota. Meningkatnya pendapatan membuat masyarakat mampu untuk membayar tarif taksi konvensional, sehingga lebih memilih menggunakan taksi karena kenyamanannya dibanding transportasi lainnya yang dirasakan gerah dan berhimpitan dengan penumpang lainnya.

2. Tarif taksi konvensional (X2) ditemukan nilai t hitung sebesar 3,837 berarti hipotesis "tarif taksi konvensional (X2) berpengaruh signifikan terhadap permintaan taksi konvensional" dapat diterima. Koefisien regresi variabel tarif taksi konvensional sebesar -0,00002064 menunjukkan bahwa arah hubungan tarif taksi konvensional terhadap permintaan taksi konvensional adalah negatif. Hal ini berarti jika variabel lain dianggap tetap dan tarif taksi konvensional meningkat sebesar 10.000 maka akan menurunkan permintaan taksi konvensional sebanyak 0,206 Unit. Hasil penelitian ini sejalan dengan penelitian yang dilakukan oleh McFadden (1974:319), Bento (2003:9), Schaller (2005:74), Yang et al (2010:347), Souche (2011:132) dan Wang \& Huang (2013:124). Fenomena yang ada bahwa tarif taksi konvensional lebih tinggi dibanding tarif angkutan umum lainnya, 
menyebabkan masyarakat yang tidak memiliki pendapatan lebih besar, akan menggunakan ojek atau angkutan kota dalam beraktivitas, namun dengan adanya peningkatan pendapatan maka masyarakat mampu untuk membayar tarif taksi konvensional.

3. Nilai t hitung untuk variabel tarif taksi online (X3) sebesar 3,779 berarti hipotesis "tarif taksi online (X3) berpengaruh signifikan terhadap permintaan taksi konvensional" dapat diterima. Koefisien regresi variabel tarif taksi konvensional sebesar 0,00004042 menunjukkan bahwa arah hubungan tarif taksi online dan permintaan taksi konvensional di Kota Makassar adalah positif. Hal ini berarti jika variabel lain dianggap tetap dan tarif taksi online meningkat sebesar 10.000 Rupiah maka akan meningkatkan permintaan taksi konvensional sebanyak 0,404 Unit. Hasil penelitian ini sejalan dengan penelitian yang dilakukan oleh McFadden (1974:319), Bento et al (2003:16) dan Souche (2011:132). Sebagaimana yang diuraikan pada hasil penelitian di atas bahwa arah hubungan tarif taksi konvensional terhadap permintaan taksi konvensional adalah negatif, sedangkan arah hubungan tarif taksi online terhadap permintaan taksi konvensional adalah positif. Arah hubungan yang bertolak belakang tersebut berarti bahwa komoditas taksi konvensional dan komoditas taksi online memiliki hubungan yang saling bersubstitusi satu dengan yang lain. Pemaknaannya bahwa tingginya tarif taksi konvensional menyebabkan penurunan permintaan terhadap taksi konvensional. Dengan demikian masyarakat akan menggunakan alternatif taksi online. Dengan demikian, keputusan masyarakat dalam menggunakan taksi online berdasarkan tarif sesuai dengan tulisan Anggraini tahun 2017 bahwa harga berpengaruh terhadap keputusan menggunakan angkutan online khususnya angkutan Gojek.

Dengan demikian terjadi hubungan subtitusi antara taksi konvensional dengan taksi online. Menurut Juniawan dan Kusuma (2017) Faktor yang dapat membuat konsumen beralih dari taksi konvensional ke taksi online adalah tarif yang terkadang diluar espektasi pelanggan. Sementara itu, kebijakan penetapan tarif yang dilakukan oleh taksi konvensional sangat tergantung pada kenaikan harga bahan bakar.
4. Waktu tunggu taksi konvensional (X4) ditemukan nilai t hitung sebesar 2,377 berarti hipotesis "waktu tunggu taksi online (X3) berpengaruh signifikan terhadap permintaan taksi konvensional". Koefisien regresi variabel waktu tunggu taksi konvensional sebesar -0,043 menunjukkan bahwa arah hubungan tarif taksi online dan permintaan taksi konvensional di Kota Makassar adalah negatif. Hal ini berarti jika variabel lain dianggap tetap dan waktu tunggu taksi konvensional bertambah selama 10 menit, maka permintaan taksi konvensional akan menurun sebanyak 0,43 unit. Hasil penelitian ini sejalan dengan penelitian yang dilakukan oleh Yang et al (2010:347), Watkins et al (2011:12) dan Mishalani et al (2013:2), Rayle et al (2014:11). Kondisi ini berarti bahwa permintaan terhadap taksi konvensional dipengaruhi oleh lamanya waktu tunggu. Makin lama waktu tunggu pemesanan, maka makin menurunkan permintaan terhadap taksi konvensional. Waktu tunggu sangat terkait dengan efektivitas proses pelayanan yang diberikan. Waktu tunggu terkait dengan proses produk sampai ke tangan konsumen. Proses (process) adalah semua prosedur aktual, mekanisme dan aliran aktivitas dengan nama jasa yang disampaikan yang merupakan sistem penyajian atau operasi jasa (Yasid, 2003) Proses yang cepat dalam pemesanan hingga terjadinya penjemputan, merupakan indikator yang menjadi penilaian masyarakat dalam memilih menggunakan taksi konvensional ataukah taksi online.

Temuan ini dimaknai bahwa manakala pemesanan terhadap taksi konvensional terlalu lama dalam waktu tunggu,maka masyarakat akan beralih menggunanan taksi online. Dengan demikian taksi konvensional dapat terus diminati apabila waktu tunggu lebih cepat atau sama dengan waktu tunggu taksi online.

5. Jenis kebutuhan (X5) ditemukan nilai t hitung yakni sebesar 4,767 berarti hipotesis "jenis kebutuhan (X5) berpengaruh signifikan terhadap permintaan taksi konvensional" dapat diterima. Hal ini sesuai dengan hasil penelitian yang dilakukan oleh Rayle, et al (2014:11) di mana jumlah penggunaan taksi untuk kebutuhan rutinitas sehari-hari seperti bekerja lebih sedikit dibandingkan jumlah penggunaan taksi untuk kebutuhan aktivitas 
sosial seperti menuju bar, restoran, konser, mengunjungi keluarga dan teman. Makin tinggi aktivitas masyarakat maka makin tinggi kebutuhan mereka untuk menggunakan taksi konvensional. Konsumen lebih memilih taksi untuk kebutuhan non rutin dan dadakan, diakibatkan karena bisa lebih fokus dan nyaman dalam berkendara karena tidak perlu mempersiapkan segala sesuatu dibanding menggunakan kendaraan pribadi apalagi angkutan kota yang harus menunggu kendaraannya penuh.

Dari 135 responden, jumlah responden berjenis kelamin laki-laki sebanyak 58 orang dan berjenis kelamin perempuan sebanyak 77 orang. Jika dilakukan split data berdasarkan jenis kelamin, di mana jumlah $\mathrm{N}$ untuk laki-laki sebanyak 58 dan jumlah $\mathrm{N}$ untuk perempuan sebanyak 77, maka hasil regresinya masingmasing sebagai berikut :

\section{Untuk responden laki-laki, $\mathrm{N}=58$}

$$
\begin{gathered}
\hat{Y}=1,641+3,242 E^{007} X_{1}-1,902 E^{005} X_{2}+4,182 E^{005} X_{3}-0,048 X_{4}+2,929 X_{5} \\
(0,063) \quad(0,000) \quad(0,008) \quad(0,005) \quad(0,082) \quad(0,001)
\end{gathered}
$$

2. Untuk responden perempuan, $\mathrm{N}=77$

$$
\hat{Y}=1,641+3,242 E^{007} X_{1}-1,902 E^{005} X_{2}+4,182 E^{005} X_{3}-0,048 X_{4}+2,929 X_{5}
$$

$$
\begin{array}{lllll}
(0,063) \quad(0,000) \quad(0,008) \quad(0,005) \quad(0,082) & (0,001)
\end{array}
$$

Dari kedua hasil regresi di atas maka tampak bahwa variabel pendapatan, tarif taksi konvensional, tarif taksi online dan jenis kebutuhan taksi konvensional berpengaruh signifikan terhadap permintaan permintaan taksi konvensional di Kota Makassar. Perbedaan daru kedua hasil regresi ini yakni pada responden yang berjenis laki-laki, waktu tunggu taksi konvensional tidak berpengaruh signifikan terhadap permintaan taksi konvensional, sedangkan untuk responden berjenis kelamin perempuan waktu tunggu berpengaruh signifikan terhadap permintaan taksi konvensional. Dengan kata lain, waktu tunggu menjadi variabel yang penting untuk pengguna taksi berjenis kelamin perempuan dalam menentukan frekuensi permintaan taksi konvensional. sedangkan responden dengan jenis kelamin laki-laki waktu tunggu tidak berpengaruh dalam menentukan frekuensi permintaan taksi konvensional di Kota Makassar.

\section{PENUTUP}

\section{Kesimpulan}

Hasil penelitian ini menyimpulkan bahwa pendapatan, tarif taksi konvensional, tarif taksi online (sebagai referensi tarif konvensional), dan jenis kebutuhan taksi konvensional memiliki pengaruh yang signifikan baik secara simultan maupun secara parsial terhadap permintaan taksi konvensional di Kota Makassar.

Kesimpulan lain dari penelitian ini yakni hubungan antara 2 komoditas yaitu taksi konvensional dan taksi online (Grab/Go-Car/Uber) memiliki hubungan yang saling bersubstitusi satu dengan yang lain. Selain itu, pengguna taksi konvensional di Kota Makassar yang berjenis kelamin perempuan lebih mempertimbangkan lamanya waktu tunggu taksi sedangkan pengguna taksi berjenis kelamin laki-laki cenderung mengabaikan lamanya waktu tunggu taksi konvensional.

Untuk mempertahankan frekuensi permintaan taksi konvensional di Kota Makassar maka manajemen taksi konvensional harus melakukan penyesuaian tarif yang lebih bersaing dengan taksi online. Pemesanan taksi konvensional oleh pelanggan taksi berjenis kelamin perempuan sebaiknya direspon lebih cepat.

\section{Keterbatasan dan rekomendasi untuk penelitian selanjutnya}

Penelitian ini hanya berfokus pada kondisi penggunaan taxi online di kota Makassar, sehingga disarankan bagi penelitiselanjutnya untuk mengkaji pada wilayah yang berbeda.

\section{DAFTAR PUSTAKA}

Acemoglu, Daron \& Friends. 2016. "Microeconomics". Global Edition. Pearson Education Limited. England.

Anwar, Ahsani Amalia, 2017, Online vs Konvensional: Keunggulan dan Konflik Antar Moda Transportasi di Kota Makassar, Etnosia: Jurnal Etnografi Indonesia, Vol2, edisi 2

Angraini, Nur Fitriah, 2017, Analisis Faktor-Faktor yang Mempengaruhi Konsumen Menggunakan Jasa Ojek Online (Studi Perbandingan Go Jek dan Ojek Online Syar'i), Fakultas Ekonomi dan Bisnis, Universitas Muhammadyah Surakarta

Bento, Antonio M et al. 2003. "The Impact of Urban Spatial Structure on Travel Demand in The United States". Policy Research Working Paper. The World Bank. March Edition. 
Case, Karl E \& Friends. 2012. "Principles of Economics". Tenth Edition. Prentice Hall. USA.

Cats, Oded et al. 2013. "Effect of Real-Time Transit Information on Dynamic Passengger Path Choice". Centre for Transport Studies. SE-100 44. Stokholm.

Elliot, Greg, Sharyn Rundle-Thiele, David Waller. 2012. Marketing, Edisi 2, Australia, John Wiley $\&$ Sons.

Hal, Robert E. \& Leiberman, Marc. 2010. "Microeconomics: Principles and Application". 5th Edition. Cengage Learning. USA.

Henderson, James Mitchell \& Quandt, Richard E. 1985. "Microeconomics Theory: A Mathematical Approach". Third Edition. McGraw-Hill Book Company. Aucland.

http://makassarkota.go.id/110geografiskotamakassar.html (diunduh15-102018)

http://berita-sulsel.com/2017/03/31/data-jumlahpenduduk-makassar-tahun-2015-hingga-2017/ (diunduh, 15-10-2018)

Fajariah, 2017, Analisis Permintaan Jasa Ojek Online di Kota Makassar, Skripsi Fakultas Ekonomi dan Bisnis, Universitas Hasanuddin Makassar

Juniawan, Eko Jefry, dan Kusuma, A.A.Gede Agung Artha, 2017 Faktor-Faktor Yang Mempengaruhi Customer Switching dari Taksi Konvensional ke Taksi Online, E-Jurnal Manajemen Unud, Vol. 6, No. 10, 2017: 54605488, ISSN: 2302-8912

Karlan, Dean \& Morduch, Jonathan. 2014. "Microeconomics". McGraw-Hill Education. USA.

Mankiw, N. Gregory. 2012. "Principles of Economics". Sixth Edition. Cengage Learning. USA.

McFadden, Daniel. 1974. "The Measurement of Urban Travel Demand". Journal of Economics 3. North Holland Publishing Company.

Mishalani, Rabi G. \& Friends. 2006. "Passenger Wait Time Perception at Bus Stops: Empirical Results and Impact on Evaluating Real-Time Bus Arrival Information". Journal of Public Transportation. Vol 9. No 2.

Parkin, Michael. 2014. "Microeconomics". Eleventh Edition. Pearson Education, Inc. United State of America.
Perkins, Dwight H. \& Friends. 2001. "Economics of Development". Fifth Edition. W. W. Northon \& Company. New York.

Pindyk, Robert S \& Rubinfeld, Daniel L. 2013. "Microeconomics". Eighth Edition. Prentice Hall. USA.

Prabawati, Dwi Karyayuris, 2017, Penerapan Strategi Pemasaran Jasa Transportasi Taksi Konvensional Blue BirdDalam Menghadapi Persaingan Jasa Transportasi Berbasis Aplikasi Online di Surabaya, Sekolah Tinggi Ilmu Ekonomi Perbanas Surabaya

Rayle, Lisa. Et al. 2014. “App-Based, On-Demand Ride Service: Comparing Taxi and Ridesourcing Trips and User Characteristics in San Francisco". University of California Transportation Center (UCTC). Working Paper.

Schaller, Bruce. 2005. "A Regression Model of The Number of of Taxicab in US Cities". Journal of Public Administration. Vol 8. No. 5.

Slavin, Stephen L. 2014. "Microeconomics". Eleventh Edition. Mc Graw Hill Education. New York.

Souche, Stephanie. 2010. "Measuring the Structural Determinants of Urban Travel Demand". Journal of Transport Policy. Elsevier.

Todaro, Michael P \& Smith, Stephen C. 2012. "Economics of Development". 11th Edition. Addison-Wesley. Pearson. United States of America.

Varian, Hal R. 2010. "Intermediate Microeconomics: A Modern Approach". Eight Edition. WW Norton Company Inc \& WW Norton Company, Ltd. New York \& London.

Wang, Xin \& Huang, Hai-Jun. 2013. "BI-Criteria System Optimum Traffic Assignment in Networks with Continous Value of Time". Promet - Traffic and Transportation. Vol 25. No 2.

Wang, Yuanqing et al. 2013. "Study of Modal Shifts to Bus Rapid Transit in Chinese Cities". Journal of Transport Engineering. May.

Waters, W.G. \& Yong, Jong Say. 1990. A Survey of Recent Estimates of Price Elasticities of Demand for Transport. Policy, Planning and Research - Working Papers - Transportation. The World Bank.

Watkins, Karl Edison et al. 2011. "Where Is My Bus? Impact of Mobile Real-Time Information on The Perceived and Actual Wait Time of 
Transit Riders". Transportation Research Part A Policy and Practice. Research Gate. October.

Yang, Hai et al. 2010. "Nonlinear Pricing of Taxi Service". Transportation Research Part AA. Elsevier.
Yazid,2003, Pemasaran Jasa: Konsep dan Implementasi, Edisi Kedua, Penerbit Ekonisia, Fakultas Ekonomi, UII Yogyakarta. 